\title{
Smallpox eradication, laboratory visits, and a touch of tourism: travel notes of a Canadian scientist in Brazil
}

\author{
Erradicando a varíola, visitando laboratórios e um pouco de \\ turismo: notas de viagem de um cientista canadense ao Brasil
}

\author{
Steven Palmer \\ Professor associado do \\ Department of History/University \\ of Windsor. \\ 401 Sunset Ave \\ N9B 3P4 - Windsor, ON - Canada \\ spalmer@uwindsor.edu

\section{Gilberto Hochman} \\ Pesquisador sênior da Casa de \\ Oswaldo Cruz/Fundação Oswaldo \\ Cruz. \\ Av. Brasil, 4036/403 \\ 21040-361 - Rio de Janeiro - \\ RJ - Brasil \\ hochman@coc.fiocruz.br
}

\section{Danieli Arbex}

Sessional Lecturer do Department of Economics/University of Windsor

401 Sunset Ave N9B 3P4 - Windsor, ON - Canada dscarbex@gmail.com
PALMER, Steven; HOCHMAN, Gilberto; ARBEX, Danieli. Smallpox eradication, laboratory visits, and a touch of tourism: travel notes of a Canadian scientist in Brazil. História, Ciências, Saúde - Manguinhos, Rio de Janeiro, v.17, n.3, jul.-set. 2010, p.777-790.

\section{Abstract}

The paper presents and discusses the travel notes diary of Canadian scientist Robert J. Wilson when he visited Brazil in April 1967 during the Smallpox Eradication Programme run by the World Health Organisation. Wilson's report makes it possible to reflect on the smallpox eradication campaign in Brazil; on the Canada-Brazil cooperation to improve the quality of the smallpox vaccine; on his assessment by of scientists and Brazilian laboratories; on the effects of intersections between scientific activity and social and cultural activities; on the role played by specialist communities of experts role in international scientific cooperation projects; and on a Canadian traveller's concepts and prejudices about Brazil at the end of the 1960s. Keywords: vaccines; smallpox; eradication; Canada; Brazil.

\section{Resumo}

A presenta e comenta o diário de viagem ao Brasil do cientista canadense Robert J. W ilson em abril de 1967, no âmbito do Programa de Erradicação da Varíola dirigido pela Organização M undial da Saúde. O relato deW ilson possibilita reflexões sobrea campanha deerradicação da varíola no Brasil; a cooperação Canadá-Brasil para a melhoria da qualidadeda vacina antivariólica; a avaliação deW ilson acerca de cientistas elaboratórios brasileiros; os efeitos das interseções entreatividade científica eatividades sociais eculturais; o papel das comunidades de especialistas em empreendimentos de cooperação científica internacional; e os conceitos e preconceitos de um viajante canadense com relação ao Brasil do final da década de 1960.

Palavras-chave: vacinas; varíola; errradicação; Canadá; Brasil. 


\section{Introduction}

In 1966, the Connaught Medical Research Laboratories, then part of the University of Toronto (today Aventis Pasteur Canada), was invited by Donald A. Henderson, director of the Smallpox Eradication Programme of the World Health Organisation (WHO), to play a leading role in supervising the quality of the smallpox vaccine. Connaught's work would involve testing the batches of vaccine produced by Latin American laboratories, visiting the actual laboratories in the region and training personnel to assure that the vaccines produced locally meet international standards (Rutty, 2008). The assistant director of Connaught, Robert (Bob) J. Wilson (1915-1989), took over the mission together with Paul Fenje (1915-2010), a vaccine specialist, who was also working in the Canadian laboratory. One of its main spokesmen in Brazil was José Fonseca da Cunha (1914-2005), head of vaccine production in the Oswald Cruz Institute (IOC) and who had trained in Connaught in 1959.

The Connaught collaboration with WHO and benchmark laboratories in Latin America characterizes the importance of what are called epistemic communities, or networks of specialists with recognised knowledge in a particular area (Haas, 1992), as valuable facilitating mechanisms working with international cooperation. Officially the Canadian government only played an indirect role in the Smallpox Eradication Programme as a WHO Member State. Canada has always been a "reluctant partner" (Dmitrienko, 2006; Dmitrienko, Birn, 2006) in regional cooperation, having joined the Pan American Health Organization (PAHO) only in 1971. Between 1967 and 1973 the Canada-Brazil scientific collaboration was run without explicit inter-government agreements (Barreto, Rutty, 2002) and strongly based on the relations between Canadian and Brazilian scientists, under the sponsorship of PAHO and WHO. The personal and professional relations between Henderson, Wilson, Fenje and Fonseca da Cunha were what boosted the cooperation between Canada and Brazil in the area of quality of the smallpox vaccine, and Henderson and Wilson were to be those who urged the Canadian government to adopt a more active role in the WHO smallpox eradication programme (Palmer, Hochman, 2010).

The Canadian laboratory's role in eradicating smallpox produced a large quantity of documents that are currently kept in the Aventis Pasteur, Connaught Campus Archives in Toronto. The collection, which has a good part of the technical documentation, helps reconstruct the scientific practices involved in the vaccine's production. The administrative and political material provides information about how the laboratories in the developed and developing countries were run, has more personal documents about scientific friendships and the nature of the collaboration, and al so addresses the disputes in the field of international health. In some case, the files contain sources that combine all these three dimensions of historic experience. One such case is Wilson's first trip to Brazil, one of the most important countries - from the geopolitical, diplomatic and epidemiological viewpoints - for the WHO Smallpox Eradication Programme, the last endemic country in the region of the Americas.

Wilson's journey in April 1967, amidst the enthusiasm in Canada for the commemorations of the country's centenary, was made during the first years of the military dictatorship in Brazil (1964-1985). His travel notes, rewritten on his return to Canada, are intriguing from the different levels of reported experiences and observations. Wilson visited IOC, Butantan, 
and the Recife and Porto Alegre laboratories. Notes about addresses and phone numbers of institutions and scientists are found alongside technical descriptions of vaccine production methods; admiration for the natural wonders, national monuments and tourist attractions; appreciation of sounds and symbols are followed by assessments of the personalities of the top scientists in public health or comments on how public administration works.

How important was it for this Canadian, involved in his own also nationalist commemorations of Canada's centenary, to understand Brazilian scientific and political nationalism? Would the quality of the hotel where he stayed or the meal in the restaurant be of importance for his opinions on the technical problems of producing the smallpox vaccine in Brazil, particularly in IOC? Would his appreciation of the quality of the laboratory facilities be affected by the unexpected interruption of children running in and out in the middle of his visit? These are questions that can be raised for history and sociology of international scientific cooperation.

Wilson's travel notes presuppose a self-attribution of higher scientific sophistication than his hosts. For example, he classifies those who are part of his community (those who graduated or trained in North America) and outsiders. But if such filters can raise questions about the reliability of his portrait of the Brazilian research institutions, should the same doubts be raised about his refined appreciation of the temperament found in the scientific community - for example, the aspirations of senior administrators in Rio de Janeiro, or low regard for the personnel in peripheral laboratories? His scathing comments about the meeting with the director of the Oswald Cruz Institute, Rocha Lagoa (who was to become the Health Minister in the years 1969 to 1972 during the darkest days of the military dictatorship) are paradigmatic from these viewpoints. Why is he dismissive about the Brazilians' experiment in someresearch areas and does positively assess the scientific capacity and of producing some vaccines, particularly for yellow fever commanded by Fonseca da Cunha? Should we take these personal views as an obstacle to scientific objectivity, or adopt the idea of how it fits and is built into his narrative?

Wilson's travel diary is a thick volume and hard to classify. He returned to the country on a scientific mission on several occasions, and in August 1973 was vice-president of the Commission that certified the smallpox eradication in Brazil. There is nothing in his dispassionate technical reports about these journeys that he sent to PAHO to indicate this almost natural combination of his personal and scientific assessments of notes made for Connaught in 1967. Perhaps it is because they are notes written under the impact of his first experience of South America. The highly personal memories of a scientific-technical visit experienced by the scientist within a certain particular social network and national culture are included in a complex field of administrative and political institutions, which forces us to reflect on what might be lost when these different dimensions are separated from each other in the history of science, medicine and public health.

\section{AUTHORS' NOTES}

The archivist reference of the document is R. J. Wilson, "Daily Memoranda - First Trip, South America," Aventis Pasteur, Connaught Campus Archives, 88-001-49. Wilson's original text, which was in essence a 
Steven Palmer, Gilberto Hochman, Danieli Arbex

draft, was preserved. In longer reports, technical sections were edited to make the document more accessible to the reader, and a brief description of what is missing can be found in brackets. A first version of the document was published in Cultures of Health - An historical anthology in 2009 (http:// hih.uwindsor.ca/wordpress/).

The study that is the basis of this article has the support of the National Council for Scientific and Technological Development (CNPq) and of Fiocruz and Canada Research Chair in History of International Health at the University of Windsor.

\section{ACKNOWLEDGMENTS}

A special thanks to doctor Luis Barreto, vice-president for Public Relations and librarian Hugh McNaught, both from Sanofi Pasteur Ltd., for their help with this project, and to doctor Christopher J. Rutty for his generous guidance in the Connaught Campus Archives. 


\section{Introdução}

Em 1966, o Connaught Medical Research Laboratories, então parte da Universidade de Toronto (hoje Aventis Pasteur Canadá), foi convidado por Donald A. Henderson, diretor do Programa de Erradicação de Varíola da Organização Mundial da Saúde (OMS), para assumir um papel central na supervisão da qualidade da vacina antivariólica. O trabalho do Connaught seria testar os lotes de vacinas produzidas por laboratórios da América Latina, realizar visitas in loco aos laboratórios da região e treinar pessoal para garantir que as vacinas produzidas na região seguissem os padrões internacionais (Rutty, 2008). O diretor adjunto do Connaught, Robert (Bob) J. Wilson (1915-1989) assumiu a missão junto com Paul Fenje (1915-2010), especialista em vacinas que também trabal hava no laboratório canadense. Um de seus principais interlocutores no Brasil foi José Fonseca da Cunha (19142005), chefe de produção de vacinas no Instituto Oswaldo Cruz (IOC) e que fizera treinamento no laboratório canadense em 1959.

A colaboração do Connaught com a OMS e laboratórios de referência da América Latina caracteriza a importância das chamadas comunidades epistêmicas, ou redes de especial istas baseadas no conhecimento (Haas, 1992), como mecanismos facilitadores e operadores da cooperação científica internacional. Oficialmente, o governo canadense teve apenas papel indireto no Programa de Erradicação da Varíola, na condição de estado membro da OMS. O Canadá sempre foi um "parceiro relutante" (Dimitrienko, 2006; Dimitrienko, Birn, 2006) na cooperação regional, tendo ingressado na Organização PanAmericana da Saúde (Opas) apenas em 1971. Entre 1967 e 1973, a colaboração científica Canadá-Brasil foi operada sem acordos explícitos entre governos (Barreto, Ruty, 2002) e baseada fortemente nas relações entre cientistas canadenses e brasileiros, sob patrocínio da Opas e da OMS. Seriam as relações profissionais e pessoais entre Henderson, Wilson, Fenje e Fonseca da Cunha que movimentariam a cooperação entre os dois países na área da qualidade da vacina antivariólica, e seriam Henderon eWilson que pressionariam o governo canadense a participar mais ativamente do programa de erradicação da varíola da OMS (Palmer, Hochman, 2010).

O papel do laboratório canadense na erradicação da varíola gerou grande quantidade de documentos, que estão atualmente sob guarda do Aventis Pasteur, Connaught Campus Archives, em Toronto. A coleção conta com boa parte da documentação técnica, que permite uma reconstrução das práticas científicas que envolveram a produção da vacina. O material político e administrativo fornece informações sobre o funcionamento dos laboratórios dos países desenvolvidos e em desenvolvimento. Encontram-se, também, documentos de cunho mais pessoal sobre amizades científicas, o caráter da colaboração e os conflitos no campo da saúde internacional. Há fontes que reúnem essas três dimensões da experiência histórica, a exemplo das que tratam da primeira viagem de Wilson ao Brasil, um dos países mais importantes geopolítica, diplomática e epidemiologicamente para o Programa de Erradicação da Varíola da OMS, por ser o último país endêmico, à epoca, na região das Américas.

A viagem de Wilson, em abril de 1967, em meio ao entusiasmo no Canadá pelas comemorações do centenário do país ocorreu durante os primeiros anos da ditadura militar 
no Brasil (1964-1985). As notas de viagem, redigidas em seu retorno ao Canadá, são intrigantes em razão dos diversos níveis de experiências e observações relatadas. Wilson visitou o IOC, no Rio de Janeiro, o Instituto Butantan, em São Paulo, e laboratórios de Recifee Porto Alegre. Notas sobre en dereços enúmeros de tel efone de instituições e cientistas encontram-se ao lado de descrições técnicas de métodos de produção de vacinas e man ifestações de admiração por bel ezas naturais, monumentos nacionais e pontos turísticos; apreciações sobre sons e símbolos são seguidas por avaliações das personalidades dos altos cientistas da saúde pública, ou comentários sobre o funcionamento da administração pública.

Era importante a compreensão do nacionalismo científico e político brasileiro, para esse canadense envolto em suas próprias comemorações, também nacionalistas, do centenário do Canadá? Suas opiniões sobre os problemas técnicos da produção da vacina antivariólica no Brasil, em particular no IOC, terão sido afetadas pela qualidade do hotel em que se hospedou ou pela refeição que fez em um restaurante? Sua apreciação das instal ações e da qual idade de um laboratório teria sido influenciada pela entrada inesperada de crianças, naquele recinto, em meio à sua visita? Essas são al gumas questões que podem ser levantadas para uma história e sociologia da cooperação científica internacional.

As notas de viagem de Wilson permitem pressupor uma autoatribuição de maior sofisticação científica que seus anfitriões. Por exemplo, classifica os que fazem parte de sua comunidade (os que se formaram ou tiveram treinamento na América do Norte) e os que estavam fora dela. Mas se tais filtros podem levantar dúvidas sobre a confiabilidade do retrato que fez das instituições de pesquisas brasileiras, o mesmo pode ser enunciado sobre a apreciação do temperamento que observou entre a comunidade científica, como a pretensão de administradores de alto nível no Rio de Janeiro, ou a baixa estima do pessoal em laboratórios periféricos? Seus comentários mordazes sobre a reunião com o diretor do IOC, Rocha Lagoa (que viria a ser ministro da Saúde entre 1969 e 1972, nos tempos mais sombrios da ditadura militar) são exemplares desses pontos de vista. Por que Wilson é desdenhoso no que concerne à experiência dos brasileiros em algumas áreas de pesquisa, e aval ia positivamente a capacidade científica e de produção de al gumas vacinas, em particular a da febre amarela, comandada por Fonseca da Cunha? Devemos tomar essas visões particulares como obstáculos à objetividade científica, ou como parte do modo como a mesma é enquadrada e construída em sua narrativa?

O diário de viagem de Wilson é obra espessa e de difícil classificação. Ele retornou várias vezes ao país em missão científica, tendo sido, em agosto de 1973, vice-presidente da comissão que certificou a erradicação da varíola no Brasil. Em nenhum dos relatórios técnicos que enviou à Opas sobre suas viagens aparece essa combinação quase natural de avaliações científicas e pessoais, encontradas nas notas que fez para os Laboratórios Connaught, em 1967 - talvez porque estas foram escritas sob o impacto de sua primeira experiência na América do Sul. As memórias altamente pessoais de uma visita tecnocientífica, feita por um cientista em meio a uma rede social particular e a um dado contexto cultural do país, inserido ainda em um campo complexo de instituições administrativas e políticas, levanos a refletir sobre o que se perde quando essas diferentes dimensões são separadas umas das outras, na história da ciência, medicina e da saúde pública. 


\section{NOTAS DOS AUTORES}

A referência arquivística do documento é R.J. Wilson, "Daily Memoranda - First Trip, South America", Aventis Pasteur, Connaught Campus Archives, 88-001-49. O texto original de Wilson, que era em essência um rascunho, foi preservado. Relatos mais longos de seções técnicas foram editados para tornar o documento mais acessível ao leitor; a síntese dos trechos suprimidos encontra-se entre colchetes. Uma primeira versão do documento foi publicada em Cultures of Health - An historical anthology, em 2009 (http://hih.uwindsor.ca/wordpress/).

A pesquisa que embasa este artigo conta com o apoio do Conselho Nacional de Desenvolvimento Científico e Tecnológico (CNPq), da Fundação Oswaldo Cruz (Fiocruz) e da Canada Research Chair in History of International Health, da University of Windsor.

\section{AGRADECIMENTOS}

Agradecemos especialmente ao doutor Luis Barreto, vice-presidente de Relações Públicas da Sanofi Pasteur Ltd.; ao bibliotecário Hugh McNaught, da mesma empresa, pela assistência prestada à nossa pesquisa; e ao doutor Christopher J. Rutty, pela orientação generosa que nos prestou no Connaught Campus Archives.

\section{REFERENCES}

BARRETO, Luis; RUTTY, Christopher J.

The speckled monster: Canada, smallpox and its eradication. Canadian Journal of Public Health, Ottawa, v.93, special insert, 11-20. 2002.

DIMITRIENKO, Klaudia.

Parceiro relutante: as relações do Canadá com a Organização Pan-Americana da Saúde (OPAS). História, Ciências, Saúde - Manguinhos, Rio de Janeiro, v.13, n.3, p.717-732. 2006.

DMITRIENKO, Klaudia A.; BIRN, AnneEmanuelle. Juggling demands: Canadian health aid to Latin America since World War II. Canadian Journal of Public Health, Ottawa, v.97, n.6, p.12-17. 2006.

\section{HAAS, Peter.}

Introduction: epistemic communities and international policy coordination. International Organizations, Cambridge, v.46, n.1, p.1-35. 1992.
PALMER, Steve; HOCHMAN, Gilberto. A Canada-Brazil network in the global eradication of smallpox. Canadian Journal of Public Health, Ottawa, v.101, n.2, p.113-118. 2010.

RUTTY, Christopher.

Canadian vaccine research, production and international regulation: Connaught Laboratories and Smallpox Vaccines, 1962-1980. In: Kroker, Kenton; Kealan, Jennifer; Mazumdar, Pauline (Ed.). Crafting immunity: working histories of clinical immunology. Ashgate: Aldershot and Burlington. p.280-289. 2008. 



\section{Daily Memoranda - Dr. R.J. Wilson}

\section{$1^{\text {st }}$ Trip South America}

Sat. April 8 - Arrived Rio 8:45 a.m. Met by Mr. Sampaio of Brazilian Light and Power. Provided us with car (black Aero Willis No. 23-66-22 - driver Helio) and letter from M cCrimmon asking us to lunch with him. Checked in at Grande Hotel Novo Mundo and joined the McCrimmons for lunch at their town house Av. Ruy Barbosa 310, $16^{\circ}$ Andar, Tel. 45-8555.

After lunch to the Jockey Club to watch races. McCrimmon's 2-year-old Expo 67 ran second. Then to Teresopolis, the McCrimmon summer home, about $130 \mathrm{~km}$ from Rio about 2500ft. altitude. Met the daughter and son-in-law Mary and Hugh Mill and daughter (II) Elizabeth - dined together.

Sun. April 9 a.m. - To the village with Nancy (Mrs. McCrimmon) and at noon met Mr. and Mrs. Court - their son-in-law is a nephew of Oswaldo Cruz and works at the institute.

Evening - with the McCrimmons alone.

Mon. April 10 - Helio drove from Rio and picked us up at 9:00 a.m. Arrived at the hotel at 10:30 a.m. and contacted PAHO. Went to PAHO office, Zone 5, at Rua Paissandu 231, Tel. 45-81-38. Meet Dr. S. R. Rao, acting for Dr. Raul Vera, who was on leave. Dr. Rao studied in Toronto at HSC and with MacHenry. Wishes to be remembered to Dr. Chute. Also met Dr. Juan Ponce de Leon, a Peruvian doctor who is consultant in Smallpox Eradication Zone $V$ and who is to accompany us on our trip. He studied at Columbia University and got his MPH there. We had lunch with him and spent the afternoon being briefed on the eradication program and planning our tour of Brazil. Dr. Aleria Macedo, Director of the program, was in Ciera. We planned to meet him on our return to Rio later in April. Dined at the Hotel Novo Mundo.

Tues. April 11 - Went with Dr. Ponce to the Institute Oswaldo Cruz (founded in 1908). Met Dr. Henrique A. Penna, Director of the Division of Virology. He used to work in the field of yellow fever with Soper, Lloyd, Mahaffey, Wilson etc. (see reprints) and now makes yellow fever vaccine. With him was Dr. J. Fonseca da Cunha who is in charge of production of calf vaccine. He visited me at Toronto in 1959. After some general exchange of information in a most amicable atmosphere, we examined their facilities for calf vaccine and their equipment. We met Dr. Rocha Lagoa and had lunch with his staff later. He is a young, energetic, ambitious, and aggressive man of about 45 who was head of the Rickettsial Division under Penna and was promoted to Director some 3 years ago. We returned after lunch to discussions with Penna and Fonseca, who speaks excellent English. Penna worked with Theiler in New York and Fonseca studied production of small pox vaccine in eggs in Texas. While Fenje and Fonseca discussed production methods, I went with Penna to see their yellow fever vaccine production. 
The yellow fever vaccine unit is a separate building erected about 15 years ago (see picture). They produce two lots per week, each about 1000 eggs. The embryos are pooled in lots of 100 and bacteriological tests done on each pool. Then the embryos are blended in Waring blenders, centrifuged, to get rid of gross debris. The material is filtered through flannel and filled into vials on which the lot numbers are etched. 1000 Embryos yield about 2 liters of fluid at a titer of 100,000 mouse LD/50 per ml. Each vial contains $2 \mathrm{ml}$. This is shell frozen and dried overnight on a manifold. They are filled with dry nitrogen and flame sealed. Each vial contains 200 doses of 0.5 c.c. so it is reconstituted to 100c.c. with ordinary saline. No preservative is used. The vials are not labeled other than for an etched lot number. They manufacture 400,000 doses per week for 8 or so months a year - for a total of 10-12 or so million doses a year. They don't lose too many eggs through bacterial contamination except in the summer months. They ignore leucosis virus and do not even test for it. The whole operation is carried out with great efficiency and simplicity using simple but ingenious techniques. They supply Brazil, other countries of South America; have supplied some to Ethiopia, and other African countries. They are quite aware that they would not meet the standards of most developed countries but this does not concern them. They make a good inexpensive product for Brazil. I was most impressed with the operation. The unit has a generator and so is not affected by power shortages and power cuts. Dined at restaurant Belacap, Hotel Luxor, Copacabana.

Web. April 12 - Again met with Fonseca and Penna. While Fenje discussed details of production, I visited Dr. Estacio Monteiro. He is working with Herpes virus, polio virus. Dr. Milovanovic is working with him. They are concerned in Rio and in São Paulo about the high incidence of polio in children who have received Sabin Vaccine - 2 doses, some 3 doses. They have received trivalent vaccine from:

(1) R.I.T. Belgium (distributed by Hemoderivat Brazil)

(2) Germany - Behringwecke

(3) Russia

(4) Yugoslavia

Note: At the Oswaldo Cruz there is a small statue in the smallpox unit dedicated to: FELISBERTO CALDERA BRANT M ARQUEZ DE BARBACENA who brought vaccinia to Brazil in slaves 1804.

The potency of type (1) is usually much below claimed potency. The potency of type (2) is usually much below claimed potency. Type (3) is usually all right. This is true of all but vaccine from Behringwecke...

[A technical analysis of their vaccines and production methods ensues.]

Also visited Dr. J. de Cervalho Loures. Mr. Binnerts had made contact with him in 1965. He had some early data on ERA strain and correspondence from Binnerts in 1965 on his desk when I went in. Also an Annual report which he had just received - very pleased.

They use the suckling mouse brain technique, which seems to produce high titer vaccine. But it al so seems very expensive. They lack equipment, electricity from a dependable source, 
and seem thoroughly depressed. I did not manage effective contact with him. Fenje saw him later. Hewould likeour latest data on ERA strain. Dined in theevening with Milovanovic.

Thur. April 13 - In the morning, more discussions with Fonseca and Penna. Lunch with the Director Dr. Rocha Lagoa. He took us to visit the new Institute of Microbiology and Immunology. It is a very large building of six floors and will mostly be occupied by relatively non-productive persons with tenure doing supposedly important research. In fact they do little. The Director has half the top floor elaborately equipped with expensive equipment not yet used. This is to do tumor research for which he is not equipped - when there are so many real problems of a practical nature which receive no support financially...

[A technical analysis of the production of vaccines at the Institute of Microbiology and Immunology ensues.]

In the p.m. to a cocktail party for one of the Deputy Director Generals of WHO Ishmirov - at the residence of Dr. Rao. Rua Almirante Gonçalves 5, Apto. 202, Copacabana Tel. 27-6183. Dined at the Copacabana Palace Hotel.

Fri. April 14 - Visited the Instituto again to clear up a few points. Returned to the PAHO office. Had lunch with Dr. Ponce de Leon and Leo Morris, a member of the eradication unit. He is a statistician on loan from CDC but taking an active part in the vaccination program.

Friday afternoon, Major McCrimmon drove us to Corcovado and to see the Monument of Christ. Dinner with the Major.

Sat. April 15 - At liberty.

Sun. April 16 - 2:30 p.m. Rio to São Paulo. Hotel Excelsior Av. Ipiranga 770, Tel. 35-5141. Dined at hotel.

Mon. April 17 - 9:30 a.m. to the Institute Butantan. Acting Director Dr. Rivera do Vale [José Ribeiro do Vale]. He is also in charge of the Department of Virology at the Instituto Adolfo Lutz. Director of smallpox production Dr. Murilo Soares. They are carrying out another polio campaign here. The last one was not too successful. Cases occurred even in the vaccinated. They are giving 2 doses to all infants and children 3 mo. - 4 years of age. I could not find out the formulation of their trivalent but type 1 is less than $10^{6.0}$. I told them of our experience with the various formulations and that Great Britain has gone back to $10^{6.0}$ type 1 . They were very interested. I also told them of the absorption to glass. Dr. Rivero de Vale would like data on formulations including Great Britain and on the absorption problem. Dr. Rivera left us with Dr. Murilo to discuss smallpox vaccine.

The facilities (space) at Butantan are very large. They have room for 20-30 calves at a time. The stabling is reasonable. They were not producing calf vaccine while we were there. They get only about $100 \mathrm{~g}$. pulp from a calf. They use about $0.063 \mathrm{ml}$. per capillary tube. The capillaries are amber and the bore diameter varies widely. Therefore the operation is very inefficient. They use about 200 calves about a year to produce about 3-4 million doses per year of glycerinated vaccine. There must be a great waste of vaccine... 
[Technical observations about their vaccines are made.]

Visited the Instituto Adolfo Lutz. Met the Director Dr. Augusto Taunay. He took us to the pox virus diagnostic unit - Dr. Luis Florêncio de Salles-Gomez. They have a reasonable diagnostic unit and he is very keen but very short of money and simple equipment such as eggs, pipettes, equipment for $\mathrm{H} 1$ tests etc. This could be a very useful diagnostic center for pox viruses. Returned to visit Dr. Taunay for a short while.

Tues. April 18 - Visited Butantan to see the procuring of venom from poisonous snakes and spiders.

Wed. April 19 - São Paulo to Porto Alegre. Arrived about 12:30 p.m. We were unable to see anyone that day or the following morning. Stayed at Hotel Lido Rua Andrade Neves, 150. Very small, clean, but very spartan. Hotel Everest would have been better.

Thur. April 20 - At 2:00 p.m. we went to the Instituto de Pesquisas Biológicas do Estado do Rio Grande do Sul [Rio Grande do Sul Institute of Biological Research]. Director - Dr. Newton Neves da Silva. Director Small pox Unit Dr. Domingos Telechea Glausell. He was in Paris so we discussed smallpox vaccine production with the Director and with Dr. Hedi Nolibos. All of these people including the Director work only part-time at the Institute.

They make only egg vaccine for an egg-adapted strain from the Lister Institute in London. It is the $3^{\text {rd }}$ passage from the Lister strain. They used to use the Hamburg strain.

The building was opened in 1961. The smallpox unit occupies 4 very small rooms, sparsely equipped. What happens when production is going on I don't know, but there seemed to be no provision for sterile hoods, etc. and children from outside were running in and out of the room containing the lyophilizing apparatus. The apparatus is an old Stokes...

[Some of the technical notes of their methods of production of vaccines ensue]

Each lot of the vaccine is tested in 20-50 humans by multiple pressure for both primary take and revaccination by a very competent and devoted public health nurse. The needles are made from bicycle spokes about 3" long although one I saw, and which is said to be used by Dr. Clausell, is about 6" long and 1/8" dia.

They seemed to get al ways $100 \%$ on primary takes and upwards of $70-80 \%$ on revaccination. The needle picks up a large drop, and the needle is wiped with wither between each vaccination. I suspect that the fairly large dose of vaccine and the vigorous technique of this capable nurse accounts in part for the excellent results. We would have to examine the vaccine to determine its ability to reconstitute, and particle size, to make any comment as to suitability for use with the jet injector.

Dr. Neves da Silva and Dr. Paulo Chaves took us to see the Secretary of Health of Rio Grande do Sul, Dr. Pereira. He is Dean of the Medical Faculty as well and teaches histology and embryology. He has visited with Dr. Ham in Toronto. He seemed pleased to co-operate in the eradication program (next year for Rio Grande do Sul). Then went to dinner with Dr. Neves and Dr. Jorge Josanni (Brazilian born Japanese). 
Fri. April 21 - National holiday in Brazil, Tiradentes. In the morning we were taken on a tour of Porto Alegre by Dr. Paulo O. Chaves Faculdade Odontologia U.F.R.G.S. [School of Dentistry, Federal University of Rio Grande do Sul]. He is a dentist and also training officer for Institute P. Biol. We went to the best parts of the city and to the favelas. Left at 1:30 for Rio - through many delays and replacement of an aircraft in São Paulo - arrived Rio 6:30 p.m.

Sat. \& Sun. April 22 \& 23 - Rio de Janeiro, Hotel Glória.

Mon. April 24 ... [Technical analysis of Brazilian program vaccines, methods, and equipment ensues]

Rio to Recife. Aircraft 5 hours late. Arrived at 9:00 p.m. Met by Dr. Augusto Vera Martinez whom we met at the PAHO office in Rio. Stayed at the São Domingo's Hotel.

Tues. April 25 - Went to see Dr. Ernesto de Oliveira the sub-zone Director for N.E. Brazil. His office is in the headquarters for S.E.S.P. (Fundação) Serviço Especial de Saúde Pública [(Foundation) Special Public Health Service], Rua Guilherme Pinto 114, Capunga, Recife, Pernambuco. (This is a special emergency system for public health set up during the war, subsidized by the U.S. and Federal Government of Brazil. Now it is supported only by the Federal Government. It is not associated with the state Government and is a duplication of service. There is little exchange of information between the S.E.S.P. and the state authorities.) Oliveira's address CAIXA POSTAL 2643, RECIFE. Dr. Oliveira is a Portuguese physician who studied at the London School and got his DPH there. He has served in Nigeria and in Korea (1952-53). He has had a good deal of experience in smallpox control in Africa with both glycerinated and lyophilized vaccine (made in Lagos).

Pernambuco (State capital [is] Recife) has a population of about 4,000,000. The chief crop is sugar. Recife has a population of about $1,000,000$. According to Time magazine (April 21), 40\% are in favelas - we saw some appalling ones there.

Three years ago they had a vaccination campaign (about $3,000,000$ or so people) and of some $\mathbf{2 8 0 0}$ or so cases of smallpox or alastrim reported in Brazil in 1966, only 6 came from Pernambuco. Some of these may have been chickenpox. Of course records are grossly inaccurate. Dr. Oliveira feels that they do not need an eradication campaign there - only a maintenance program.

At noon we visited Olinda, the original Portuguese settlement of the early 1500's on the outskirts of Recife. It is on a hill - the many churches are, for the most part, abandoned and except for the seaside where there are some good houses, the rest is filled with favelas.

In the afternoon we went to the Department of Public Health - Departamento de Saúde do Estado de Pernambuco. There is a number of divisions, including the Laboratório de Produção de Vacina Antivariólica [Smallpox Vaccine Production Laboratory]. There we met:

The Director, M. Ricardo Costa Carvalho

Departamento de Saúde Pública

Rua Oswaldo Cruz, Recife,

Pernambuco, Brazil. 
He is particularly interested to obtain data on Sabin vaccine - formulations, Bonim's paper, etc.

Prof. Helio Mendonça

Who is in charge of their virus laboratories, including smallpox vaccine and rabies vaccine, as well as teaching at the Medical School.

Co-ordinator of Laboratories Dr. Pinheiro.

Studied at McGill for 2 years (very young) ....

[An analysis of their facilities, equipment, and vaccine production follows, and the document breaks off, unfinished.] 